\title{
GIF-SUR-YVETTE NATURAL RADIOCARBON MEASUREMENTS I
}

\author{
J. COURSAGET and J. LE RUN
}

Radiocarbon Laboratory, Centre National de la Recherche Scientifique Gif-sur-Yvette (Essonne), France

The following list shows the age measurements carried out from 1958 to March 1963 at the Radiocarbon Laboratory at Gif-sur-Yvette. This laboratory has been replaced by a new one whose first measurements are also given in this volume.

It was equipped with 2 proportional counters similar to those used in Saclay laboratory and operating with $\mathrm{I}$ atm of pure $\mathrm{CO}^{2}$. These counters were shielded by $15 \mathrm{~cm}$ lead, $5 \mathrm{~cm}$ iron and $1.5 \mathrm{~cm}$ of mercury.

Data have been calculated on the basis of a $\mathrm{C}^{14}$ half-life of $5570 \mathrm{yr}$, in agreement with the decision of the Fifth Radiocarbon Dating Conference. As a modern carbon standard, wood taken from old furniture was used. This standard was found equivalent to $95 \%$ of the activity of the NBS oxalic acid, if a $2 \%$ Suess-effect is adopted for this wood.

\section{SAMPLE DESCRIPTIONS}

I. ARCHAEOLOGIC SAMPLES

\section{A. Southern France}

\section{Perte du Cros series, Saillac, Lot}

Burnt wheat from Hearth III at entrance of cave of Perte du Cros, Saillac, Lot (44 $20^{\prime} \mathrm{N}$ Lat, $1^{\circ} 37^{\prime} \mathrm{E}$ Long). Coll. 1957 by A. Calan; subm. by J. Arnal, Treviers, Herault.

\section{Gsy-35 A. Perte du Cros}

$4210 \pm 150$

\section{Gsy-35 B. Perte du Cros}

2260 B.C.

$4800 \pm 130$

2850 B.c.

General Comment: associated with Middle Neolithic of Chasséen type (Galan 1958); Gsy-35 A may be contaminated. There are Heidelberg unpublished dates from this site.

\section{Roucadour series, Lot}

Burnt wheat from stratified Neolithic levels in Doline de Roucadour, Thémines, Lot ( $44^{\circ} 50^{\prime} \mathrm{N}$ Lat, $1^{\circ} 30^{\prime} \mathrm{E}$ Long). Coll. 1956 by $\mathrm{A}$. Niederlender; subm. by Dr. J. Arnal (Coursaget et al., 1960) .

Gsy-36 A. Roucadour A $5940 \pm 150$

From Early Neolithic level. 
Gsy-36 B. Roucadour B

$5190 \pm 140$

From Middle Neolithic B 1 level.

Gsy-36 C. Roucadour C

$4280 \pm 125$ ated.

From Middle Neolithic B 2 level. Comment: somewhat contamin-

General Comment: there are Heidelberg unpublished dates from this site.

\section{Grotte de l'Eglise series, Var}

Charcoal from Neolithic site at $60 \mathrm{~m}$ in interior of Grotte de l'Eglise, Baudinard, Var -Gorges du Verdon $\left(43^{\circ} 45^{\prime} \mathrm{N}\right.$ Lat, $6^{\circ} 15^{\prime} \mathrm{E}$ Long). Coll. 1959 and subm. by J. Courtin, Centre de la Recherche Scientifique, Marseille, France (Courtin, 1959).

\section{Gsy-112 A. Grotte de l'Eglise, Layer 5}

$4510 \pm 125$

Associated with end of Middle Neolithic (Chasséen)

2560 B.c.

\section{Gsy-112 B. Grotte de l'Eglise, Layer 9}

eramics.

Associated with Middle Neolithic (Chasséen) ceramics. General Comment: in good range of dates for meridional Chasséen Neolithic.

\section{Gsy-77. Trou Arnaud, Drôme}

$4140 \pm 135$

2190 B.c.

Wheat and wood from cave called Trou Arnaud, Saint-Nazaire-leDésert, Drôme (44 $34^{\prime} \mathrm{N}$ Lat, $5^{\circ} 17^{\prime} \mathrm{E}$ Long), Coll. 1958 and subm. by A. Blanc, C.N.R.S. Comment: associated with ceramics and artifacts of Middle Neolithic Chasséen style. A somewhat older date would have been expected (Blanc, 1956).

\section{Gsy-57. La Bouissière, Var}

$3975 \pm 130$

2025 B.c.

Patch of resin and charcoal, from under the under-paving in the megalithic cist of La Bouissière, Cabasse, Var $\left(43^{\circ} 25^{\prime} \mathrm{N}\right.$ Lat, $6^{\circ} 15^{\prime} \mathrm{E}$ Long). Coll. 1950 and subm. by G. Bérard, Direction de la Circonscription des Antiquités Préhistoriques, Draguignan, Var. Comment: agrees with grave goods of the tomb, of Late Neolithic or Chalcolithic appearance (Bérard, 1954).

\section{Gsy-116. La Grotte Murée, Montpezat (Basses-Alpes, France) \\ $3960 \pm 175$ \\ 2010 B.c.}

Charcoal from Layer 6 from sealed stratigraphy of la Grotte Murée (Courtin, 1962), Montpezat, Basses-Alpes -Gorges du Verdon $\left(43^{\circ} 45^{\prime} \mathrm{N}\right.$ Lat, $6^{\circ} 15^{\prime} \mathrm{E}$ Long) . Coll. 1960 and subm. by J. Courtin. Comment: in very good agreement with associated campaniform beakers. 


\section{Gsy-37. Les Côtes de Roquefort, Aveyron

Carbonized acorns from Chalcolithic ossuary in cave of Les Côtes de Roquefort, Saint-Romé de Cernon, Aveyron $\left(44^{\circ} 0^{\prime} \mathrm{N}\right.$ Lat, $2^{\circ} 55^{\prime} \mathrm{E}$ Long) . Coll. 1947-1950 and subm. by L. Balsan, Direction de la Circonscription des Antiquités Préhistoriques de Clermont-Ferrand. Comment: dates nicely the Chalcolithic of the Grands Causses.

\section{Gsy-38. Aven du Gendarme, Aveyron \\ $3890 \pm 150$}

Charcoal from falling-in of aven-cave called the Aven du Gendarme, La Roque Sainte-Marguerite, Aveyron ( $44^{\circ} 05^{\prime} \mathrm{N}$ Lat, $3^{\circ} 10^{\prime} \mathrm{E}$ Long). Coll. 1959 and subm. by L. Balsan. Comment: agrees with ceramics of the Chalcolithic of the Grands Causses type.

\section{Gsy-120. Castello de Ceccia 3, Porto-Vecchio, $\quad 3295 \pm 110$ Corsica \\ 1345 B.C.}

Charcoal from lower layer of archaeological filling of the torrean monument of Castello de Ceccia, Porto-Vecchio, Corsica $\left(41^{\circ} 35^{\prime} \mathrm{N}\right.$ Lat, $9^{\circ} 15^{\prime}$ E Long). Coll. 1961 and subm. by R. Grosjean, C.N.R.S., Paris. Comment: this type of monument is of the series of Corsican torre most like the archaic nuraghi of Sardinia.

\section{Gsy-58. Filitosa, Corsica}

$3150 \pm 150$ 1200 B.C.

Charcoal from hearth in Cella I of a circular torrean monument of the complex site of Filitosa, Sollacaro, Corsica $\left(41^{\circ} 45^{\prime} \mathrm{N}\right.$ Lat, $8^{\circ} 0^{\prime} \mathrm{E}$ Long). Coll. 1959 and subm. by R. Grosjean. Comment: comparable to other dates of Corsican torre (Grosjean, 1961).

\section{Tappa series, Corsica}

Charcoal from interior of circular torrean monument (Grosjean, 1962), Tappa, Porto-Vecchio, Corsica (41 $35^{\prime} \mathrm{N}$ Lat, $9^{\circ} 15^{\prime} \mathrm{E}$ Long). Coll. 1960 and subm. by R. Grosjean.

\section{Gsy-94 A. Tappa I}

$2630 \pm 200$

Last occupation of the monument.

\section{Gsy-94 B. Tappa II}

680 B.C.

Sample from near foundations of the monument. Probably dates an occupation preceding the monument.

General Comment: to be compared with the other dates of Corsican torre.

\section{Malpas series}

Charcoal from the Oppidum of Malpas, Soyons, Ardèche $\left(44^{\circ} 50^{\prime} \mathrm{N}\right.$ Lat, $4^{\circ} 45^{\prime}$ E Long). Coll. and subm. by A. Blanc. 
Gsy-141. Malpas, Level 2

Gsy-142. Malpas, Level 4

$2230 \pm 105$

Gsy-143. Malpas, Level 6

280 B.c.

$2470 \pm 105$

520 B.c.

Gsy-144. Malpas, Level 7

$2580 \pm 110$

630 B.C.

General Comment: a site with occupation during whole Iron age.

\section{Abri du Facteur series, Tursac, Dordogne}

Charred bone from hearths from the Abri du Facteur, Tursac, Dordogne $\left(45^{\circ} 0^{\prime} \mathrm{N}\right.$ Lat, $1^{\circ} 5^{\prime} \mathrm{E}$ Long) (Delporte, 1962). Coll. 1957-1959 and subm. by H. Delporte, C.N.R.S., 19 Avenue de la Libération, Montbrison, Loire.

\section{Gsy-67. Abri du Facteur G $1+2$}

Layer G, with Aurignacian I industry.

\section{Gsy-69. Abri du Facteur B $13+4$}

Layer B 1, with Upper Perigordian industry. General Comment: date Gsy-69 corresponds to layer containing a Venus; date Gsy-67 may be younger than expected.

\section{B. North, East, Central France}

\section{Gsy-39. La Brèche au Diable, Calvados}

$4790 \pm 150$

2840 B.c.

\section{5,940 в.C.}

$23,180 \pm 1500$

Charcoal from Neolithic hearth (No. 2), situated inside rampart of promontory-camp of La Brèche au Diable, Mont-Joly, Soumont-SaintQuentin, Calvados ( $48^{\circ} 55^{\prime} \mathrm{N}$ Lat, $0^{\circ} 5^{\prime} \mathrm{W}$ Long). Coll. 1954 and subm. by B. Edeine, C.N.R.S., Caen. Comment: fits with the ceramics, of Chasséen type (Edeine, 1960).

\section{Gsy-97. Fort-Harrouard, Eure et Loir}

$4400 \pm 125$

2450 B.c.

Charcoal from Level I, Hearths 128 and 133, from site of Fort-Harrouard, Sorel-Moussel, Eure-et-Loir ( $48^{\circ} 45^{\prime} \mathrm{N}$ Lat, $1^{\circ} 25^{\prime}$ E Long). Coll. about 1930 by Abbé J. Philippe and subm. by G. Bailloud, C.N.R.S., Paris. Comment: dates the Middle Neolithic level, of Chasséen affinities, of this celebrated settlement (Bailloud, 1964).

\section{Gsy-32. Les Matignons, Charente}

$4570 \pm 200$

2620 B.c.

Charcoal from Level C 3 of the filling of the interior ditch of Neolithic camp of Les Matignons (Burnez et al., 1958), Juillac-le-Coq, Charente (45 $40^{\prime} \mathrm{N} \mathrm{Lat,} 0^{\circ} 15^{\prime} \mathrm{W}$ Long). Coll. 1958 and subm. by C. Burnez, 
41 rue de Bellefonds, Cognac, Charente. Comment: dates end of Chasséen utilization of the site.

Gsy-49. Montagne de Lumbres, Pas de Calais

Charcoal from Layer B of Neolithic habitation site of La Montagne de Lumbres, Lumbres, Pas-de-Calais $\left(50^{\circ} 40^{\prime} \mathrm{N}\right.$ Lat, $2^{\circ} 15^{\prime} \mathrm{E}$ Long $)$. Coll. 1958 and subm. by Dom R. Prévost, St. Omer, Pas-de-Calais. Comment: date agrees with Chasséen Middle Neolithic ceramics and industry (Prévost, 1962).

\section{Gsy-71. Biard, Charente}

$4435 \pm 200$

Charcoal from bottom of the filling of the ditch of Neolithic camp of Biard, Segonzac, Charente $\left(45^{\circ} 40^{\prime} \mathrm{N}\right.$ Lat, $0^{\circ} 15^{\prime} \mathrm{W}$ Long). Coll. 1959 and subm. by C. Burnez. Comment: this camp belongs to the Peu-Richard culture.

Gsy-114. Les Mournouards II, Marne

$3750 \pm 150$

Charcoal from artificial sepulchral cave, Les Mournouards, Le Mesnil-sur-Oger, Marne (48 $50^{\prime} \mathrm{N}$ Lat, $4^{\circ} 0^{\prime}$ E Long). Coll. 1960 and subm. by A. Leroi-Gourhan, Faculté des Lettres, Paris. Comment: associated with Late Neolithic industry of Seine-Oise-Marne culture (Leroi-Gourhan, 1962).

\section{Gsy-91. Cys-la-Commune, Aisne}

$3320 \pm 110$

1370 B.c.

Charcoal from a sort of "henge-monument" with concentric circles, inner ditch, on a terrace on the river Aisne (Jouillié, 1962), Cys-la-Commune, Aisne $\left(49^{\circ} 25^{\prime} \mathrm{N}\right.$ Lat, $3^{\circ} 35^{\prime} \mathrm{E}$ Long). Coll. 1960 and subm. by $\mathrm{H}$. Jouillié, 3, rue du Docteur Brocard, Vailly-sur-Aisne. Comment: Middle Bronze age.

Gsy-110. Videlles, Locus 5, Seine-et-Oise

$$
2930 \pm 250
$$

980 B.C.

Charcoal from settlement of les Roches (Bailloud, 1958), Videlles, Seine-et-Oise ( $48^{\circ} 25^{\prime} \mathrm{N}$ Lat. $2^{\circ} 30^{\prime} \mathrm{E}$ Long). Coll. and subm. by G. Bailloud. Comment: sample was expected to come from a Late Neolithic level, but it appears to correspond to Middle and Late Bronze age material above it.

\section{Gsy-85. Cronenbourg, Bas-Rhin}

$3215 \pm 150$

Carbonized apples and wood from a potter's kiln, in an underground excavation, Cronenbourg, Strasbourg, Bas-Rhin $\left(48^{\circ} 35^{\prime} \mathrm{N}\right.$ Lat, $7^{\circ} 45^{\prime}$ E Long). Coll. 1959 and subm. by J. J. Hatt, Faculté des Lettres, Strasbourg. Comment: the ceramics from the potter's kiln correspond to Late Bronze age II of E France, expected age between 1050 and 950 B.c. 
$3075 \pm 175$

Gsy-62. La Viaube, Vienne

1125 B.C.

Charcoal, from Middle Bronze Age settlement, La Viaube, JaunayClan, Vienne $\left(46^{\circ} 40^{\prime} \mathrm{N}\right.$ Lat, $0^{\circ} 20^{\prime} \mathrm{E}$ Long) (Coursaget et al., 1961). Coll. 1948 and subm. by M. Taillet, Massy-Verrières, Seine-et-Oise. Comment: in good agreement.

\section{Gsy-84. Charmodot, Côte-d'Or}

Charcoal from hearth in a barrow at Charmodot, Villecomte, Côted'Or (47 $20^{\prime} \mathrm{N}$ Lat, $5^{\circ} 07^{\prime}$ E Long). Coll. 1960 and subm. by R. Ratel, 8 Bd. Thiers, Dijon, Côte-d'Or. Comment: this barrow contains sepulchres between the Late Bronze age and early La Téne period; its internal structures are very complex (Ratel, 1965).

\section{Gsy-113. Royat, Puy-de-Dôme}

$$
2110 \pm 100
$$

Carbonized wood from ruins of a burnt building, on S side of Puy Chateix, Royat, Puy-de-Dôme $\left(45^{\circ} 45^{\prime} \mathrm{N}\right.$ Lat, $3^{\circ} 05^{\prime} \mathrm{E}$ Long). Coll. 1961 and subm. by P. Fournier, Director of Historic Antiquities, ClermontFerrand. Comment: no archaeological clue to date of building.

\section{Gsy-117. La Bellière, Maine-et-Loire}

$1760 \pm 95$

Wood from a tank, Gallo-Roman mines of La Bellière, Saint-PierreMontlimart, Maine-et-Loire ( $47^{\circ} 15^{\prime} \mathrm{N}$ Lat, $1^{\circ} 0^{\prime} \mathrm{W}$ Long). Coll. 1900 by A. Poilane; subm. by A. Champigneulle, 9 R. d'Anjou, Leste, Maineet-Loire. Comment: in good agreement (Giot, 1963) .

\section{Gsy-60. Gorges, Manche}

$$
1500 \pm 100
$$

Wood from a dug-out canoe, found at depth of $2.10 \mathrm{~m}$ to $2.40 \mathrm{~m}$ in peat-bog of Gorges, in Carentan marsh, Manche $\left(49^{\circ} 20^{\prime} \mathrm{N}\right.$ Lat, $1^{\circ} 15^{\prime}$ W Long). (Coll. 1956 and subm. by H. Elhai, Mus. Natl. d'Histoire Naturelle, Paris. Comment: dug-out appears to be late Gallo-Roman or Dark-age.

\section{Gsy-48. La Garnache, Vendée}

$$
970 \pm 100
$$

Charcoal from fire in central pit of a feudal motte, La Garnache, Vendée $\left(46^{\circ} 50^{\prime} \mathrm{N}\right.$ Lat, $1^{\circ} 45^{\prime} \mathrm{W}$ Long). Coll. 1959 and subm. by $\mathrm{F}$. Eygun and P. R. Giot, Laboratoire d'Anthropologie Préhistorique Rennes (Ille-et-Vilaine). Comment: in the expected range of dating.

\section{Gsy-41. Alençon, Orne}

\section{A.D. 1100}

$850 \pm 100$

Wood from medieval fortification from Alençon, Orne $\left(48^{\circ} 25^{\prime} \mathrm{N}\right.$ Lat, $0^{\circ} 5^{\prime}$ E Long). Subm. 1958 by du Mesnil du Buisson, 63, rue de Varenne, Paris. 


\section{Gsy-45. Richemont, Charente}

Charcoal from souterrains of a castle built during 1lth century, and sacked in 1179, Richemont, Charente $\left(45^{\circ} 40^{\prime} \mathrm{N}\right.$ Lat, $0^{\circ} 20^{\prime} \mathrm{W}$ Long). Coll. 1958 by Abbé J. Boucherit; subm. 1959 by J. Hennessy, Ecole Polytechnique, Paris. Comment: agrees with numerous sherds of 13th and 14th century found in these souterrains, possibly used for potter's workshop after destruction of castle.

\section{Gsy-34. La Garenne, Indre}

$11,230 \pm 500$ 9280 B.c.

Charcoal cinders and charred bone from a lower hearth from Magdalenian site of La Garenne (Allain, 1961), Saint-Marcel, Indre $\left(46^{\circ} 34^{\prime}\right.$ $\mathrm{N}$ Lat, $1^{\circ} 30^{\prime} \mathrm{E}$ Long). Coll. 1953 and subm. 1959 by J. Allain, $15 \mathrm{Bd}$. Gambetta, Bourges, Cher. Comment: this hearth was stratigraphically between those dated L $399 \mathrm{D}$ and C577-578-579.

\section{Western France: Brittany}

\section{Gsy-64. Ile Bono, Côtes du Nord}

$5195 \pm 300$

3245 B.C.

Charcoal from bottom of chamber of a ruined passage grave, Ile Bono, Les Sept-Iles, Perros-Guirec, Côtes-du-Nord $\left(48^{\circ} 50^{\prime} \mathrm{N}\right.$ Lat, $3^{\circ} 30^{\prime}$ W Long). Coll. and subm. 1959 by P. R. Giot. Comment: one of oldest passage graves with Middle Neolithic ceramics.

\section{Curnic series I, Guissény, Finistère}

Charcoal from submerged Neolithic settlement site on beach of Curic, Guissény, Finistère (48 $35^{\prime} \mathrm{N}$ Lat, $4^{\circ} 25^{\prime} \mathrm{W}$ Long). Coll. and subm. 1959 by P. R. Giot.

\section{Gsy-47 A. Curnic}

$4600 \pm 200$

Charcoal disseminated in the old ground and coll. in 1959.

\section{Gsy-47 B. Curnic}

$5980 \pm 150$

Charcoal from a single hearth, coll. in 1960.

General Comment: the settlement site contains ceramics and implements from the Middle and possibly early Late Neolithic. Date GRN-1966, $5340 \pm 60$ (Groningen IV), and date Gsy-47 A span the evidence of the artifacts. Date Gsy-47 B is a hint to the presence of Early Neolithic populations on this coast.

\section{Mané-Miguel series, Carnac, Morbihan}

Charcoal from small cists in interior of huge mound of ManéMiguel (Mont-Saint-Michel), Carnac, Morbihan $\left(47^{\circ} 35^{\prime} \mathrm{N}\right.$ Lat, $3^{\circ} 05^{\prime}$ W Long). Coll. 1900-1906 by Z. Le Rouzic; subm. by P. R. Giot. 


\section{Gsy-89. Mané-Miguel Y}

$4980 \pm 150$

3030 B.C.

Gsy-90. Mané-Miguel Z

$8800 \pm 300$

6850 B.c.

General Comment: Gsy-89 corresponds to beginning of Middle Neolithic, and goes well with present ideas about date of large mounds of the Carnac group. But Gsy-90 is very extraordinary, and can only be explained by the use of sub-fossil wood from a peat-bog for some ritual fire.

Compare with date Sa-96 from central funeral vault of same monument, a date rather older than could be expected: $5840 \pm 300$ (Saclay I).

\section{Gsy-56. Le Restudo, Côtes-du-Nord}

$4830 \pm 150$

Cinders and charcoal from a layer, covered by $1.20 \mathrm{~m}$ of earth, near chapel of Restudo, Saint-Pever, Côtes-du-Nord $\left(48^{\circ} 25^{\prime} \mathrm{N}\right.$ Lat, $3^{\circ} 5^{\prime} \mathrm{W}$ Long). Coll. and subm. 1959 by P. R. Giot. Comment: shows site to be a Neolithic habitation place.

\section{Gsy-111. Kerléven, Finistère}

$4825 \pm 125$

Charcoal from chamber of a passage-grave with compartimented chamber, at Saint-Laurent, Kerléven, La Forêt-Fouesnant, Finistère $\left(47^{\circ}\right.$ $55^{\prime} \mathrm{N}$ Lat, $3^{\circ} 55^{\prime} \mathrm{W}$ Long). Coll. and subm. 1961 by J. L'Helgouach, Laboratoire d'Anthropologie, Rennes. Comment: associated with Middle Neolithic ceramics, in good agreement with other dates for passage graves (L'Helgouach, 1965).

\section{Gsy-88. Mané-Kernaplaye, Morbihan}

$4585 \pm 200$

2635 в.c.

Charcoal from passage grave of Mané-Kernaplaye, Saint-Philibert, Morbihan ( $47^{\circ} 35^{\prime} \mathrm{N}$ Lat, $3^{\circ} 05^{\prime} \mathrm{W}$ Long). Coll. 1938 by Z. Le Rouzic; subm. 1960 by P. R. Giot. Comment: these collective tombs having being in use during long periods of the Neolithic, it is always the oldest date which gives the nearest approximation for the construction (Giot, 1962).

\section{Gsy-31. Cojoux, Ille-et-Vilaine}

$4270 \pm 120$

2320 B.C.

Charcoal from a Late Neolithic long barrow, La Croix-Saint-Pierre, Grée de Cojoux, Saint-Just, Ille-et-Vilaine $\left(47^{\circ} 40^{\prime} \mathrm{N}\right.$ Lat, $2^{\circ} 0^{\prime} \mathrm{W}$ Long) . Coll. 1953-1954 and subm. by P. R. Giot, 1958. Comment: agreement with the grave goods.

\section{Gsy-73. Kerméné, Morbihan}

$4030 \pm 110$

2080 B.c.

Charcoal from a Late Neolithic barrow, Kermené, Guidel, Morbihan (47 $45^{\prime} \mathrm{N}$ Lat, $3^{\circ} 30^{\prime} \mathrm{W}$ Long). Coll. 1958 and subm. 1960 by P. R. Giot. Comment: associated with Late Neolithic ceramics and artifacts, and fragments of a broken statue menhir. 


\section{Curnic series II, Guissény, Finistère}

Charcoal from hearths in pits corresponding to a Late Bronze age salt-pan industry, submerged site on the beach of Curnic, Guissény, Finistère ( $48^{\circ} 35^{\prime} \mathrm{N}$ Lat, $4^{\circ} 25^{\prime} \mathrm{W}$ Long). Coll. and subm. 1962 by P. R. Giot.

\section{Gsy-47 C. Curnic}

$\mathrm{W}$ pit.

\section{Poulguen series, Finistère}

Wood and charcoal from T-shaped passage grave, under a barrow, of Poulguen, Penmarc'h, Finistère $\left(47^{\circ} 45^{\prime} \mathrm{N}\right.$ Lat, $4^{\circ} 20^{\prime} \mathrm{W}$ Long). Coll. by A. du Châtellier, 1862, and A. Martin and P. du Châtellier, 1902; subm. 1959 by P. R. Giot.

\section{Gsy-55 A. Poulguen 1902}

$1460 \pm 105$

Charcoal from a secondary use of the tomb. Comment: site has given some Gallo-Roman material.

\section{Gsy-55 B. Poulguen 1862}

$3560 \pm 120$

Wood from a sort of flooring. General Comment: agrees with a very late Neolithic (Secondary Neolithic) dating of this special monument (Giot, 1961).

\section{Gsy-86. Kervellerin, Morbihan}

$3295 \pm 150$

1345 B.c.

Charcoal from Middle Bronze Age barrow, Kervellerin, Cléguer, Morbihan $\left(47^{\circ} 50^{\prime} \mathrm{N}\right.$ Lat. $3^{\circ} 20^{\prime} \mathrm{W}$ Long). Coll. and subm. 1960 by $\mathrm{P}$. R. Giot. Comment: date A comes from charcoal found in the funeral vault itself; date $\mathbf{B}$ from charcoal disseminated in earth of the barrow.

\section{Gsy-42. Saint-Bugan, Côtes-du-Nord}

$2520 \pm 110$

Charcoal from hearth next to a hoard of 800 socketed axes of Late Bronze age, Saint-Bugan, Loudéac, Côtes-du-Nord $\left(48^{\circ} 10^{\prime} \mathrm{N}\right.$ Lat, $2^{\circ}$ $45^{\prime}$ W Long). Coll. and subm. 1959 by P. R. Giot. Comment: good proof that Late Bronze age armorican socketed axes are contemporary with Early Iron age elsewhere.

\section{Grée de Carate series, Morbihan}

Charcoal from small barrows on Grée de Carate, Pluherlin, Morbihan $\left(47^{\circ} 40^{\prime} \mathrm{N}\right.$ Lat, $2^{\circ} 20^{\prime} \mathrm{W}$ Long) (Giot, 1960). Coll. 1957-1958 by A. Lepart; subm. 1958 by P. R. Giot. 


\section{Gsy-33. Grée de Carate No. 9}

Gsy-46. Grée de Carate No. 15

General Comment: confirms that these barrows are Late Bronze age and Early Iron Age. To be compared with date GRN-1973, $2650 \pm 60$ (Groningen IV).

\section{Gsy-107. Kervernier, Côtes-du-Nord}

$2635 \pm 175$

Charcoal from artificial souterrain of the Iron age, Kervenier, Pluzunet, Côtes-du-Nord (48 $35^{\prime}$ N Lat, $3^{\circ} 20^{\prime}$ W Long). Coll. 1960 by J. R. Geoffroy; subm. 1961 by P. R. Giot. Comment: several hundred years older than expected.

Gsy-63. Kervénarc'hant, Finistère

Charcoal from an Iron age souterrain, Kervénarc'hart, PleyberChrist, Finistère $\left(48^{\circ} 25^{\prime} \mathrm{N}\right.$ Lat, $3^{\circ} 55^{\prime} \mathrm{W}$ Long). Coll. and subm. 1959 by P. R. Giot. Comment: a few centuries older than expected.

\section{Gsy-87. Kerlescan, Morbihan}

$2360 \pm 110$

Carbonized acorns from the long barrow at Kerlescan Carnac, Morbihan ( $47^{\circ} 35^{\prime} \mathrm{N}$ Lat, $3^{\circ} 05^{\prime} \mathrm{W}$ Long). Coll. 1942 by M. Jacq; subm. 1960 by P. R. Giot. Comment: a Neolithic date was expected.

\section{Barnenez series, Finistère}

From the reutilization of the different passage-graves of the great cairn or Barnenez, Plouézoch, Finistère ( $48^{\circ} 40^{\prime} \mathrm{N}$ Lat, $3^{\circ} 51^{\prime} \mathrm{W}$ Long). Coll. 1955-1956 and subm. 1962 by P. R. Giot.

\section{Gsy-30. Barnenez E}

Burnt grains and plants.

\section{Gsy-147. Barnenez C}

Charcoal.

General Comment: large collective tombs such as the 11 passage graves of the cairn of Barnenez have been revisited at various times.

\section{Ras-Shamra series, Syria}

$$
\text { D. Asia }
$$

Charcoal from monuments of Ras Shamra, North Syria $\left(35^{\circ} 37^{\prime} \mathrm{N}\right.$ Lat, 35 $48^{\prime}$ E Long). Coll. 1958, 1960 and subm. 1961 by C. F. A. Schaeffer, College de France, Paris. 
Gsy-102. Ras Shamra 60 No. 7

From old Neolithic level, probing of the Temple of Baal, topographic point 125 , depth $12.15 \mathrm{~m}$. Comment: $1000 \mathrm{yr}$ older than expected from P-459 and P-458 V (Pennsylvania VI) .

Gsy-104. Ras Shamra 58 No. 11

$3070 \pm 200$

1120 B.c.

From Late Bronze age III level, dromos of Tomb I, S small palace of Ugarit. Comment: agrees with P-462.

\section{Mundigak series, Afghanistan}

Charcoal from site of Mundigak (Casal, 1961), near Kandahar, Afghanistan (32 $30^{\prime} \mathrm{N}$ Lat, $65^{\circ} 30^{\prime}$ E Long). Coll. 1956-1958 and subm. 1959 by J. M. Casal, C.N.R.S., Paris.

Gsy-50. Mundigah CCCXXIV

$3945 \pm 150$

Period I, Layer 5 (Neolithic).

1995 B.c.

Gsy-51. Mundigak CCIV

$2995 \pm 110$

Period III, Layer I.

1045 в.c.

Gsy-52. Mundigak CCCII

$3480 \pm 115$

Period II, Layer 1.

1530 B.c.

Gsy-53. Mundigak CXXXII

$4185 \pm 150$

2235 B.c.

Period III, Layer 5.

General Comment: there are numerous difficulties in this sequence of dates.

\section{Enkomi-Alasia series, Cyprus}

Charcoal from site Enkomi-Alasia, near Famagouste, Cyprus $\left(35^{\circ}\right.$ $07^{\prime} \mathrm{N}$ Lat, $33^{\circ} 57^{\prime} \mathrm{E}$ Long. Coll. $1959-1960$ and subm. 1961 by C. F. A. Schaeffer.

Gsy-105. Enkomi 59 No. 13

$2850 \pm 200$

900 B.C.

From topographical point 239, depth $2 \mathrm{~m}$, extreme end of Late Bronze age, Late Cypriot III ("close style" of the Mycenian chronology). Comment: younger than expected.

Gsy-106. Enkomi 60 No. 14

$3280 \pm 110$

1330 B.c.

From topographic point 512, Z.74, depth $1.20 \mathrm{~m}$, Cypriot Iron age I (corresponding to Mycenian III C $1 / 2$ ). Comment: slightly older than expected.

General Comment: samples 105 and 106 appear to have been inverted. 


\section{Tehad series, Africa}

$$
\text { E. Africa }
$$

Charcoal from habitation mounds in Chari delta, $17 \mathrm{~km} \mathrm{~N}$ of FortLamy, Tchad $\left(12^{\circ} 30^{\prime} \mathrm{N}\right.$ Lat, $15^{\circ} \mathrm{E}$ Long). Coll. and subm. 1960 by J. P. Lebeuf, C.N.R.S., Paris.

Gsy-92. Maguira, Tchad, No. 148

Gsy-93. Mdaga, Tehad, No. 69

Gsy-109. Tedgaoust No. 2, Mauritania

Charcoal from Tedgaoust, Pit 1 bis, Mauritania $\left(17^{\circ} \mathrm{N} \mathrm{Lat,} 12^{\circ} \mathrm{W}\right.$ Long). Coll. and subm. by J. Devisse, 1961, Faculté des Lettres, Dakar, Sénégal. Comment: result identical to Sa-219: $150 \pm 100$ (Saclay I).

\section{F. South and Central America}

\section{Sambaqui series, Paraña, Brasil}

Charcoal from sambaqui kitchen-middens, Paraña, Brasil. Coll. 1958 and subm. 1960 by A. Laming-Emperaire, Faculté des Lettres, Paris.

\section{Gsy-79. Sambaqui Guaraguassu, Paraña}

Gsy-78. Sambaqui José Viéra VIII

Gsy-82. Sambaqui José Viéra VI

Gsy-80. Sambaqui José Viéra IV

\section{Gsy-81. Sambaqui José Viéra II}

\section{Gsy-61. Mixco Viejo, Gautemala}

Charcoal from bottom of a wall, near and under Structure A 9, ruins of Mixco Viejo, Guatemala ( $14^{\circ} 38^{\prime} \mathrm{N}$ Lat, $90^{\circ} 22^{\prime} \mathrm{W}$ Long). Coll. 1957 and subm. 1959 by H. Lehmann, Musée de l'Homme, Paris.

\section{Gsy-100. Ortega 3/L6, Costa Rica}

$2195 \pm 130$

Charcoal from hearth in site of Ortega, Guanacaste province, Costa Rica (31 $20^{\prime} \mathrm{N}$ Lat, $112^{\circ} 40^{\prime} \mathrm{W}$ Long), Coll. 1960 and subm. 1961 by C. Baudez, C.N.R.S., Paris. Comment: corresponds to the expected age.

\section{La Bocana series, Costa Rica}

Charcoal from cave of La Bocana, Guanacaste province, Costa Rica ( $31^{\circ} 20^{\prime} \mathrm{N}$ Lat, $112^{\circ} 40^{\prime} \mathrm{W}$ Long). Coll. 1960 and subm. by C. Baudez. 
Gsy-98. La Bocana 1/G1

Gsy-99. La Bocana 1/M3

General Comment: somewhat later than expected.

\section{Gsy-74. Chillon Valley, Peru}

Human bones from basis of a scree, in Chillon Valley, Central Peru (11 ${ }^{\circ} 50^{\prime} \mathrm{S}$ Lat, $76^{\circ} 37^{\prime} \mathrm{W}$ Long). Coll. 1958 and subm. 1960 by O. Dollfus, French Embassy, Lima, Peru.

\section{GEOLOGIC SAMPLES-FRANCE}

\section{Gsy-95. La Motte d'Aveillans, Isère}

Fossil wood of Picea from interglacial clay of La Motte d'Aveillans, near La Mure, Isère (44 $55^{\prime} \mathrm{N}$ Lat, $5^{\circ} 45^{\prime} \mathrm{E}$ Long). Coll. and subm. 1960 by L. Moret, Faculté des Sciences, Grenoble.

\section{Gsy-135. Appeville 2, Cotentin}

$6950 \pm 170$

5000 B.C.

Peat from 3.05 to $3.10 \mathrm{~m}$ in sub-littoral peat-bog of Carentan, at Appeville, Manche $\left(49^{\circ} 20^{\prime} \mathrm{N}\right.$ Lat, $1^{\circ} 15^{\prime} \mathrm{W}$ Long). Coll. and subm. 1961 by H. Elhaï. Comment: on palynological evidence corresponds to Sub-boreal phase, but date agrees with Atlantic phase (Elhaï, 1963).

\section{Gsy-75. Brignogan, Finistère}

$4980 \pm 120$

Peat from submerged peat bog on beach of Chardons Bleus, Brignogan, Finistère $\left(48^{\circ} 42^{\prime} \mathrm{N}\right.$ Lat, $4^{\circ} 40^{\prime} \mathrm{W}$ Long). Coll. and subm. 1960 by M. T. Kerfourn, Inst. de Géologie, Rennes, who has studied it palynologically (Kerfourn, 1960). Comment: Zone VII of Atlantic period in good agreement.

\section{Gsy-59. Lingreville, Manche}

$1435 \pm 200$

Peaty mud from Level C No. 43 of submerged bog of Lingreville, Manche ( $48^{\circ} 55^{\prime} \mathrm{N}$ Lat, $1^{\circ} 35^{\prime} \mathrm{W}$ Long). Coll. 1958 and 1959 by H. Elhaï, Rouen. Comment: younger than expected, as level is covered by a laver with Gallo-Roman pottery of the 1st century A.D.

\begin{tabular}{|c|c|}
\hline ate lists: & REFERENCES \\
\hline Groningen IV & Vogel and Waterbolk, 1963 \\
\hline Pennsylvania VI & Stuckenrath, Jr., 1963 \\
\hline Saclay I & Delibrias, Guillier and Labeyrie, 1964 \\
\hline Saclay II & Delibrias, Guillier and Labeyrie, 1965 \\
\hline
\end{tabular}

Allain, J., 1961, Premier aperçu d'ensemble sur l'industrie magdalénienne de la Garenne, Saint-Marcel: Bull. de la Société Préhistorique Française, v. 58, p. 594-604. Bailloud, G., 1958, L'habitat néolithique et protohistorique des Roches, Videlles: Mémoires de la Société Préhistorique Française, v. 5, p. 192-214. 
1964, Le Néolithique dans le Bassin Parisien: 2ème supplément à GalliaPréhistoire, 394 p. (C.N.R.S.).

Bérard, G., 1954, Le dolmen de la Bouissière, Cabasse: Bulletin de la Société Préhistorique Française, v. 51, p. 281-288.

Blanc, A., Coquillat, M., 1956, Le "Trou Arnaud" à Saint-Nazaire-le-Désert: Cahiers Rhodaniens, v. 3, p. 22-32.

Burnez, C., Drion, G., Grafe, P., 1958, Sondages dans le camp néolithique des Matignons, Juillac-le-Coq: Bulletins et Mémoires de la Société Archéologique et Historique de la Charente.

Casal, J. M., 1961, Fouilles de Mundigak: Mémoires de la Délégation archéologique Francaise en Afghanistan, v. 17.

Coursaget, J., Giot, P. R., Le Run, J., 1960, Neolithic dates from France: Antiquity, v. 34, p. $147-148$.

Coursaget, J., Giot, P. R., Le Run, J., 1961, New radiocarbon dates from France: Antiquity, v. 35 , p. 147-148.

Courtin, J., 1959, Les peintures schématiques de la Grotte de l'Eglise: Revue d'Etudes Ligures, v. 25, p. 186-195.

1962, La grotte murée de Montpezat: Cahiers Ligures de Préhistoire et d'Archéologie, v. 11, p. 248-256.

Delporte, H., 1962, Etude paléo-topographique d'un habitat du périgordien supérieur: Bulletin de la Société Préhistorique Française, v. 59, p. 345-353.

Edeine, B., 1960, Du site de la Brèche-au-Diable, Soumont-Saint-Quentin: Bulletin de la Société Préhistorique Francaise, v. 57, p. 331-333.

Elhaï, H., 1963, La Normandie occidentale entre la Seine et le Golfe Normand-Breton: Thèse Lettres, Paris, 1963, 626 p.

Galan, A., 1958, La station de la Perte du Cros et la transition Néo-Enéolithique: Actes du 4ème Congrès régional de Spéléologie, Région Sud-Ouest, Cahors, p. 43-55.

Giot, P. R., 1960, Vers une échelle chronologique "absolue" pour la préhistoire et la protohistoire armoricaines: Annales de Bretagne, v. 67, p. 33-44.

1961, Chronique des datations radiocarbone armoricaines: Annales de Bretagne, v. 68 , p. 21-24.

1962, Chronique des datations radiocarbone armoricaines: Annales de Bretagne, v. 69, p. 29-35.

1963, Chronique des datations radiocarbone armoricaines: Annales de Bretagne, v. 70 , p. 93-96.

Grosjean, R., 1961, Filitosa et son contexte archéologique: Fondation Piot, Monuments et Mémoires, P.U.F., v. 52, no. 1, 102 p.

1962, Le gisement torréen fortifié de Tappa, Porto-Vecchio: Bulletin de la Société Préhistorique Française, v. 59, p. 206-217.

Jouillié, H., 1962, Découverte dans la vallée de l'Aisne d'une tombe à incinérations multiples entourée de deux fossés concentriques: Bulletin de la Société Préhistorique Française, v. 59, p. 324-332.

Kerfourn, M. T., 1960, Etude sédimentologique des formations quaternaires de la région de Brignogan: Bulletin de la Société Géologique et Minéralogique de Bretagne, p. 1-72.

Leroi-Gourhan, A., Bailloud, G., Brézillon, M., 1962, L'hypogée II des Mournouards, Mesnil-sur-Oger: Gallia-Préhistoire, v. 5, no. 1, p. 23-133.

L'Helgouach, J., 1965, Les sépultures mégalithiques en Armorique; Thèse Sciences, Rennes, 1966, $330 \mathrm{p}$.

Prévost, R., 1962, L'habitat néolithique de la Montagne de Lumbres: Mémoires de la Commission Départementale des Monuments Historiques du Pas-de-Calais, v. 11, $94 \mathrm{p.}$

Ratel, R., 1965, Les tumulus de Villecomte: III, tumulus de "Charmodot": Revue Archéologique de l'Est et du Centre-Est, v. 16, p. 75-101.

Stuckenrath, Jr., R., 1963, University of Pennsylvania radiocarbon dates VI: Radiocarbon, v. 5, p. 82-103.

Vogel, J. C., and Waterbolk, H. T., 1963, Groningen radiocarbon dates IV: Radiocarbon, v. 5 , p. $163-202$. 